goodwill have had his generous help with counsel and speech regardless of time or trouble. Students from foreign lands, especially perhaps China and Egypt, have been drawn to his school of geography and have found in him, as have all his students, not only a teacher but also a friend. Now Prof. Roxby is to go to Chungking at the invitation of the British Council to be a chief cultural link between China and Britain. He thus crowns a life's work at the University of Liverpool with a high adventure of goodwill.

\section{Royal Institute of Chemistry: \\ Retirement of Mr. R. B. Pilcher, O.B.E.}

THE recent announcement of the approaching retirement of $\mathrm{Mr}$. R. B. Pilcher from the office of registrar and secretary of the Royal Institute of Chemistry will have been received with much regret by all members and friends of the Institute. Mr. Pilcher joined the staff of the Institute as clerk in 1892, was appointed secretary in 1895 and registrar and secretary in 1900, and will thus, on his retirement next year, have completed fifty years service as secretary. To all members Mr. Pilcher's name is inseparable from that of the Institute, and it is to his loyalty, devotion and care that the success of the Institute is largely due. In Mr. Pilcher a sense of the human values is highly developed and his administration of the affairs of the Institute bears the impress of his character and personality. To many chemists he has been a very present help in trouble. As registrar and secretary of the Institute, Mr. Pilcher has become acquainted with, and has gained the esteem of, most of the leading British chemists of the past half-century, and he has, by his gracious manner and personality, established and maintained cordial relations with Government departments and other authorities. Mr. Pilcher has shown much interest in the earlier history of chemistry and has made a large and valuable collection of engravings of alchemists and alchemical apparatus. His lectures on "Alchemists in Art and Literature" and on "A Century of Chemistry : From Boyle to Priestley", published by the Institute, have given pleasure to many. Mr. Pilcher's literary gifts are shown not only in these lectures but also in his book, "The Profession of Chemistry", and in the more important "History of the Institute : 1877-1914". When the time comes, the good wishes of his friends, and they are many, will go with Mr. Pilcher into his retirement.

\section{Committees on Agricultural Education}

THe Minister of Agriculture and Fisheries and the President of the Board of Education have jointly appointed a committee to advise them on all aspects of agricultural education to be provided by local education authorities, and particularly on the educational policy and methods of training to be adopted at farm institutes. The committee, which will be a permanent body, is constituted as follows: Dr. Thomas Loveday, vice-chancellor of the University of Bristol (chairman); Mr. F. Barraclough, secretary to the North Riding of Yorkshire Education Committee; Dr. J. Ewing, H.M. inspector of schools; Mrs. F. C. Jenkins, assistant director, Women's Land Army; Mr. C. Bryner Jones, formerly Welsh secretary of the Ministry of Agriculture; Mr. L. R. Missen, director of education for East Suffolk; Mr. A. E. Monks, an organizer of the National Union of Agricultural Workers now serving as labour liaison officer to the Minister; Mr. W. A. Stewart, county agricultural organizer and principal of the Northamptonshire Institute of Agriculture; Dr. G. K. Sutherland, H.M. inspector of schools; Mr. R. A. Ward, chairman of the Development and Education Committee of the National Farmers' Union; Prof. J. A. Scott Watson, Sibthorpian professor of agriculture in the University of Oxford.

The Minister of Agriculture has also appointed a committee to consider the character and extent of the need for higher agricultural education in England and Wales and to make recommendations as to the facilities which should be provided to meet the need. This committee will deal with agricultural education provided by agricultural colleges and university departments of agriculture, and will take over the functions of the Ministry's war-time Committee on Higher Agricultural Education. The committee consists of Dr. Thomas Loveday (chairman); Mr. R. Beloe, chief education officer for Surrey ; Mr. D. G. Brown, farmer and member of the war-time Com. mittee on Higher Agricultural Education, member of the Agricultural Improvement Council; $\mathrm{Mr}$. George Brown, an agricultural organizer of the 'Transport and General Workers' Union and member of the Hertfordshire War Agricultural Executive Committee ; Dr. Charles Crowther, principal of Harper Adams Agricultural College and acting director of the National Institute of Poultry Husbandry; Sir Frank Engledow, professor of agriculture in the University of Cambridge, member of the Agricultural Research Council ; Mr. C. Bryner Jones (also a member of the Joint Committee); Mr. T. Neame, horticulturist, governor of Wye College, member of Kent Agricultural Education Committee; Prof. E. J. Salisbury, director of the Royal Botanic Gardens, Kew, member of the Agricultural Research Council and of the University Grants Committee; Dr. G. K. Sutherland (also a member of the Joint Committee); Miss D. S. Tomkinson, member of the Worcestershire County Council and chairman of the Agricultural Sub-Committee of the National Federation of Women's Institutes; Mr. L. G. Troup, county agricultural organizer for Hampshire and executive officer of the County War Agricultural Executive Committee ; Mr. J. Turner, vice-president of the National Farmers' Union.

The secretary of both Committees is Mr. F. L. Wormald, Ministry of Agriculture and Fisheries, Block 4, Bickenhall Mansions, Baker Street, W.1.

\section{Artificial Insemination of Cattle}

Tне Minister of Agriculture and Fisheries has recently arranged for a review of the principles on which the development of artificial insemination centres in England and Wales should be planned and controlled. Discussions have taken place with the National Cattle Breeders' Association, the National Farmers' Union and the Milk Marketing Board. It is considered that artificial insemination centres should be controlled and developed as a national service on behalf of the livestock industry and that, with the exception of centres established for experimental purposes, licences for such centres should be granted in future only to organizations controlled and financed by producers, such as the Milk Marketing Board, farmers' co-operative societies and the cattle breed societies. It would be a condition of the licence that the centre would be available to all producers of cattle within the area of operation. A Central Advisory Committee is being appointed to advise the Minister upon the economic aspects of the control 